UDK 78(4-014)"15"

\author{
Lilian P. Pruett
}

North Carolina central University, Durham

Centralna univerza severne Karoline, Durham

\title{
Central Europe in the Sixteenth Century: A Musical Melting Pot
}

\author{
Srednja Evropa v šestnajstem stoletju: \\ glasbeni talilni lonec
}

SUMMARY

After briefly reviewing the problems arising from attempts to dentify precise geographical outlines of Central Europe in the course of time, the author opts to use the limitations existing in the sixteenth century, the time frame of the presentation. This means, essentially, the borders of the Habsburg homelands, i.e., the southeastern part of the Holy Roman Empire. The paper argues that the roots of Central European musical practices were established through the foundation of regulated institutional entities such as the imperial chapels of Maximilian I (1496) and other rulers (Albrecht V of Bavaria, 1550), their successors and imitators, as well as the transalpine Renaissance church centers. As these institutions were staffed by musicians coming from virtually every corner of Europe - each practitioner bringing his own territorial contribution with him - the emerging musical consciousness of the Central European region had as cosmopolitan a foundation as that of Europe at large. Still, the proximity of the Central European art music scene to the variety of local ethnic traditions may be interpreted as lending a flavor to the musical expression of the area, endowing it with a character of its own. While in its beginnings the recipient of many influences from multinational contributors, in a later, equally cosmopolitan period (the Classicism of the eighteenth century), Central Europe reciprocates in equal measure, its contributions exerting impact upon European music in general.
POVZETEK

Po kratkem pregledu problemov, ki jih prinesejo poskusi identificiranja natančnih geografskih obrisov Srednje Evrope skozi zgodovino, avtorica predlaga uporabo zamejitev, ki so obstajale v šestnajstem stoletju, časovnem okviru prezentacije. To $\mathrm{v}$ bistvu pomeni: meje habsburških dežel, t.j. jugovzhodni del Svetega rimskega cesarstva. Prispevek zagovarja stališče, da so korenine glasbenih praks Srednje Evrope pognale $z$ nastankom vodenih institucionalnih entitet, kot so dvorna kapela Maximiliana I (1496) in drugih vodij (Albreht V bavarski, 1550), njihovih naslednikov in posnemovalcev, kakor tudi transalpinskih renesančnih cerkvenih središč. Z naraščanjem števila prihajajočih glasbenikov iz virtualno vsakega koščka Evrope in vsak udeleženec je prinesel svoj teritorialni delež s seboj je porajajoča se glasbena zavest regije Srednje Evrope imela enako kozmopolitsko osnovo kot Evropa v celoti. Povezanost srednjeevropske glasbene scene $\mathrm{z}$ raznolikostjo lokalnih etničnih tradicij je mogoče razumeti kot nekaj, kar podeljuje okus glasbenemu izrazu tega področja, puščajoč mu samosvoj značaj. Na začetku recipient mnogih vplivov multinacionalnih ustvarjalcev, Srednja Evropa kasneje $\mathrm{v}$ enako kozmopolitskem obdobju (klasicizmu 18. stoletja) deluje vzajemno v enaki meri. In njeni prispeveki $\mathrm{k}$ zunajevropski glasbi so veliki. 
As I began to marshal my thoughts in preparation for this gathering devoted to the probing of a Central European musical identity, I faced two immediate questions of definition. The first and obvious one concerns this entity we refer to as Central Europe. Like most of you here in this room, I have an idea of what I mean when I use the term, but when I started to put precise geographical borders to this concept, I began to run into difficulties. The preliminary paper by our host, Dr. Klemenčič, on the topic, ${ }^{1}$ which he kindly made available through the internet at the time the invitations were issued, presented a brief overview of the complications. The borders of "Central Europe" exhibit great elasticity depending on what century of history one considers, ranging from a re-drawing of the Habsburg holdings at different times, to various twentieth-century constructs. A significant contributing factor in one's final image of what the area encompasses is the motivation of the person doing the considering, whether one is driven primarily by cultural, artistic, and intellectual impulses, or by political and commercial considerations. In recent history, that is, within the last three decades, references to Central Europe have generally had to do with politics and economics and, more often than not, they have claimed legitimacy of the nomenclature essentially only for the original three 1991 signatories of the Visegrad group: Poland, Hungary, and Czechoslovakia. In that restricted view, the Cold-War function of Central Europe was to provide a third area between Western Europe and the Soviet-dominated East. Also, there was a clear demarcation line between this Central Europe and the Balkans farther to the south. The demarcation was strengthened when the named countries joined NATO and applied for admission to the European Union. But note that the borders are shifting again: since Slovenia will become part of the EU in 2004, the line for the Balkans will slip slightly southward. The new demarcation line seems to be now determined less by geography and more by the religious division of Roman Catholicism and Orthodoxy. And let us not forget that the serious topic of mapping Central Europe also admits some opportunities for levity, or at least they strike me as such. There have been some maps drawn that would divide Europe into horizontal bands for Northern, Central, and Southern Europe, with the Central band stretching from the French Atlantic coast through the Czech Republic and Slovakia, while another one suggests a vertical banding reaching from Finland to the Mediterranean Sea, sandwiched between Western and Eastern Europe. ${ }^{2}$ Clearly, the question of Central Europe remains in a state of flux. Several weeks ago, in the International Herald Tribune, I encountered an article suggesting that Vienna was resuming its "old position" as capital of Central Europe, while another one stated that the eastern border of Central Europe is to be sought at the right bank of the Danube river in Novi Sad, with the Balkans starting at the left bank.

In my opinion, these kinds of political interpretations of Central Europe may be challenging and problematic in their own ways, but are not practical in a discussion that intends to probe abstract intellectual, cultural, societal, and spiritual interrela-

\footnotetext{
1 Music History Beyond Borders and the Borders of the Musical Central Europe, available on http://www.oeaw.ac.at/ mufo/agora/klemencic.html

2 Vaclav Pinkava, "Lateral Thinking on the Meaning of Central Europe Today," in Central Europe Review, 28 June 1999.
} 
tionships, rather than transitory political and commercial alliances, which are subject to changing ideological or temporary pragmatic orientations. For instance, some of the recent purely political mappings categorically deny any Central European validity to the German-speaking area. However, such exclusion is inappropriate in the cultural sphere. In fact, there would have to be a drastic revisionist rewriting of history to accommodate such a Draconian separation. For, like it or not, the many centuries of Habsburg rule did put an imprint upon many facets of the area's constituent nations. Thus, as my time frame is mainly the sixteenth century, I shall opt for the area valid at that time: the lower half of the Holy Roman Empire including a part of Italy, the lands controlled by the House of Habsburg.

This brings me to the second element in need of definition: remember that I started out saying that there were two areas needing clarification. To my mind, the concept of "music" needs to be delimited as well. As I understand this probing towards a regional musical identity, the implied focus is art music, a phenomenon separable from ethnic or folk music, popular music, or utilitarian music, notwithstanding the significant cross-pollinations that may occur among them. Folk music cannot be of concern here, since, by definition, each individual area populated by a recognizable ethnic group is likely to give its own distinct ethnic flavor to its music - not open to a larger region-wide interpretation, but rather intrinsically hostile to it.

For good measure, I might as well clarify how I interpret the concept of identity. Identity is an idea tied to individualism; it describes the properties and characteristics that enable us to recognize and set apart one individual from another. The concept can be expanded to communities, characteristics separating groups from one another. We may speak of national identities; the stereotypical images of the reserved and stiff-upper-lip English, the logical and analytical French, the voluble and emotional Italian, the serious and humorless German, or the melancholy, long-suffering Russian come to mind. Regardless of the superficiality of this stereotypical approach, we must admit that there is a grain of truth to it. When we attempt to posit something like a regional musical identity, on one hand, we narrow down the group concept to a limited group, namely the practitioners and adherents of an art, and on the other hand, enlarge it to a region which is home to diverse populations of many nationalities. Obviously, the complexities multiply. The notion that such a regional musical identity may reveal itself is, perhaps, unusual. But I do believe that it is a defensible one. I also believe it requires us to leave behind the superficialities of temporal political thought and delve deep into the historical past, a past whose events exerted their impact upon the emergence of such a musical identity. This kind of identity is not something that arises quickly, but evolves over ages, subject to continuous fluctuation.

While music is arguably coeval with the history of mankind, a large part of the region in question, the core of our amorphous Central Europe, remained musically nearly a blank page far longer than the countries of Western Europe, that is, as far as recorded evidence is concerned. This is not to imply that there was no musical activity, only that, for a long time, such activity did not significantly extend beyond parochial confines. I also fully acknowledge the role the Roman church played in this 
scenario. As new lands were being won for Christianity, they adopted the growing musical codification that accompanied the development of the liturgical order - and that very practice becomes one factor contributing to the eventual emerging identity. But what I am looking for is a time when art music takes hold in the broader general life of the region, when it becomes institutionalized as an establishment with a recorded history, setting down a musical genetic code. From those beginnings it could grow into a living entity sending out roots, absorbing nourishment from various sources, and emerging with an identity that succeeding generations could draw upon, albeit altering, modifying, and enriching it according to their own needs. The process may be comparable to the development of an individual personality inheriting certain parental traits and characteristics which are then molded by environment and outside influences, and, indeed, by personal choices as the individual matures.

A historical event that set into motion such a defining germinative process can actually be pinpointed. I believe it was the establishment of the Imperial Chapel in the reign of Holy Roman Emperor Maximilian I in 1498. From the very first moment, this institution revealed a diversity in its components that survived through the ages as the body grew into a formative musical center. In fact, the Imperial Chapel became the fountainhead from which a recognizable musical identity could emerge. The original inspiration to establish this regional organization was not home-grown: Maximilian used the famous musical chapel of the Burgundian dukes as his model, the chapel whose musical character had been shaped by Dufay and his contemporaries Binchois, Busnois, Ghizeghem and others. ${ }^{3}$ Remember that Maximilian came to know the Burgundian Chapel very well when he took Mary, the daughter and heir of the last Burgundian duke, Charles the Bold, to be his wife in 1477 . Twenty years later, far from the then-dominant musical west, Maximilian commanded that a comparable unit be established at his court in Vienna, and the person he chose to create and mold this new body was Georg Slatkonja, native of Ljubljana. A product of his native region, a graduate of the university of Vienna, and the eventual Bishop of Vienna, Slatkonja proceeded to build a musical establishment that would come to rival, perhaps even outshine any other of its time. That first chapel, active in Vienna, Linz, and Innsbruck may be seen as the seed of organized art music in the Central European region. Slatkonja's musical chapel was highly successful and visible; it provided the model to be admired and envied. (There is an artistic reminder of the chapel's glory in Maximilian's famous "Triumphzug," the set of woodcuts by Hans Burgkmair, in which the court musicians are immortalized for posterity. We also have a sizeable surviving repertory.) In 1519, however, this magnificent chapel faced dissolution after the death of Emperor Maximilian, who was almost penniless at the time. His successor, Charles V, disbanded the organization: his own interests lay with his own Flemish and Spanish Chapels, not the distant one in the eastern reaches of the Empire, and Maximilian's musicians scattered in all directions. However, revival of the musical body came under Ferdinand I, who first renewed the chapel's charter

3 Although Dufay spent most of his life in papal service, he does appear listed as chaplain in the Burgundian chapel (perhaps an honorary position?) and his music was certainly well known there. 
in 1527, when he was King of Bohemia and Hungary, then reaffirmed it in 1564, when Ferdinand became Holy Roman Emperor after the abdication of his older brother, Charles V. The chapel soon regained its prominence and it continued under Maximilian II, and on through succeeding centuries. This second incarnation of the imperial chapel, at different times headquartered in various locations throughout the Central European region, is the objective of my attention, as it attracted and absorbed musicians and composers from wide-ranging geographical areas, thus ensuring that many streams contributed to the foundations of an emerging musical identity. Not the least reason for the international character of the musical atmosphere of the age was the multinational familial intertwining of the ruling house, the Hapsburgs, with many of the most notable European dynasties. Let me remind you that Ferdinand I married Anna Jagiellonska of the Polish royal line, and thus their children - several of whom became very important for the musical furtherance in their respective lands - were half Polish. The younger generations, in turn, married into Polish, Italian, German, and French royalty and nobility, thus sustaining the internationalization of the culture.

As for the music, composers, singers, and performers were recruited from all corners; let me mention just a few names. Large numbers came from the Netherlands, not surprising, in view of the prominence of Netherlandish musicians at the time. Among the best known immigrants are Jacob Vaet, Philippe de Monte, Jacob Regnart, Carl Luython, Christopher Hollander, Jacobus de Kerle. From Italy came Giovanni Gabrieli, Annibale Perini, Simone Gatto, Josephus Dusinelli. From France, Guillaume Costeley, Alard Gaucquier. From Rumania, Silesia, and Bohemia, came Valentin Bakfark, Thomas Stoltzer, The Newsidler brothers, Jan Turnovský, Christof Harant. Poland provided Wacław Szamotułczik, Nicholas Gomólka. From Spain came Mattheus Flecha, Francisco de Novo Portu, Hieronymus Ramirez, and so on. These men brought their musical backgrounds with them: contrapuntal techniques from the Netherlands, liking for full sonorities and textural clarification from Italy, instrumental practices from many different areas. Interestingly, the imperial trumpeter choir (as listed in the court payment records) frequently came from a single place; for example, in 1551, the entire band of twelve brass players came from Brescia. At other times, Udine appears prominently and repeatedly in the lists. When these instrumentalists provided entertainment at meals - which was one of their daily duties - they reportedly played improvised rather than written out compositions, and it is likely that folk songs and dances from their respective home areas were part of their repertories, thus introducing many strands into the developing musical language. ${ }^{4}$

The cosmopolitan atmosphere at court was reflected in the urban and church centers. Thus we find Jacobus Gallus (Handl/Petelin, 1550-1591), a native Slovenian, first in Vienna as member of the imperial chapel, later celebrated as composer in Olomouc and Prague. Slovenia provided some lesser lights as well, among them Andreas Reinschall of Ljubljana, who served as subcantor at St. Stephen's in Vienna.

\footnotetext{
4 This may be gleaned from a letter of Wilhelm of Bavaria to Archduke Karl of Styria, as quoted in Hanna Schäffer, "Maria von Bayern und die Musik. Musikmäzenatentum am bayrischen und am innerösterreichischen Hof,"Zeitschrift des historischen Vereines für Steiermark 83 (1992), p. 244.
} 
In that capacity he taught the choirboys, and also left his legacy as scribe of several large choirbooks in which the Mass repertory of the imperial chapel is preserved. ${ }^{5}$ Musical practices of the central tradition were disseminated far into the outlying areas: for example, the "Zinggenplaser" Joannes Fiamengo, a brass player at the courts of Karl in Graz and Albrecht II in Munich in the later 1560s, is recorded as a member of the Ducal Chapel in Dubrovnik (in 1554 and 1560). Netherlanders, Frenchmen, and Italians served in important positions in towns of the Adriatic littoral and elsewhere in the central European region. I shall cite only the three generations of Courtoys in Dubrovnik (Lambert senior, Henri, Lambert junior) between 1553 and 1664; in Cracow there was Luca Marenzio (1596-98), Annibale Stabile, and Claudio Merula; and Georg Kugelmann, who came from the court in Graz, served for a number of years in Ljubljana, before returning to Graz.

In short, I believe that at its roots the musical identity of the central European lands was forged much in the same way as it was in the western reaches: through the contributions of a widely diverse group of musicians coming together from many places, then following essentially similar stylistic paths. This is especially demonstrable during the first truly cosmopolitan period of music history, the sixteenth-century Renaissance, in which there is a great amount of stylistic conformity from one region to another. In the seventeenth century, much of Central Europe is more isolated, no doubt in large measure owing to the dominant non-artistic events, the Thirty-Years War and the Ottoman incursions. Thus, local growth spurts-or, conversely, a slowing down of activities - are more typical during that time span. But in the following eighteenth century, the period of perhaps the most intense cosmopolitanism, musical Central Europe revives with a vengeance. Let me remind you of the Bohemian source of one of the dominant Classical incubation centers: the court orchestra of Mannheim; or, of the significant roles of Vienna and Prague, both centers receptive to, and in frequent exchange with, the musical atmosphere of the more distant reaches of Central Europe. Is there anyone who truly believes that Haydn's music would be exactly what it is had he spent his entire life in, say, Hamburg, Paris, or London rather than at Eszterháza? Or that Jan Ladislaus Dussek had no impact on the newly developing Romantic piano style? The wide range is easily documentable: we have Mysliveček celebrated for his oratorios in Italy; Vanhal writing symphonies in Varaždin; Jarnović creating violin concerti in France, and so on. Thus, using the viewpoint of a broad historical perspective, I suggest that, at its foundations, the Central European musical identity is, in fact, a Pan-European one. On the other hand, I posit that the Western musical identity of today would have no resemblance to the reality we know, were we to remove the Central European region from it.

\footnotetext{
5 Berlin 40025, Brussels 27086, Vienna 15946. For a more detailed discussion on Reinschall see Lilian Pruett, "SixteenthCentury Manuscripts in Brussels, Berlin, and Vienna: Physical Evidence as a Tool for Historic Reconstruction," in Revue belge de musicologie vol. L (1996), pp. $274 \mathrm{ff}$.
} 